\title{
DNA multilayer film for loading and release of DNA oligomer
}

\author{
Y. Kamimura and N. Kato* \\ Graduate School of Science and Technology, Meiji University, Kawasaki 214-8571, Japan
}

\begin{abstract}
The Layer-by-Layer (LbL) method using polyelectrolytes is a typical strategy for preparing functional polymeric multi-layered films. Besides the electrostatic force between positively and negatively charged polyelectrolytes, the hybridization force between complementary DNA strands can be also used for building the DNA LbL films. Herein, we report the thermal responsible DNA LbL film that is designed to release specific DNA oligomers (10 bases) at an elevated temperature. Because the temperature and the ionic strength (IS) of the medium affect the hydrogen bonds in the double stranded DNA, the structural stability of the film against temperature and IS was investigated. The loading and release of the releasable oligomers were repeatedly performed on the DNA LbL film.
\end{abstract}

\section{Introduction}

The Layer-by-Layer (LbL) method was developed for the formation of thin polymer films by alternatively adsorbing positively and negatively charged polyelectrolytes on a charged surface [1]. With the aid of the template-assisted method, the LbL method can be applied for preparing functional polymeric capsules for smart drug carriers [2-4]. So far, the LbL method has been proven to be a powerful and versatile tool for various applications [5, 6].

Analogous to the use of positively and negatively charged materials as building blocks in the LbL films [1, 2], the DNA LbL films are also constructed from complementary pairs of oligonucleotides [7-14]. The physicochemical properties of the films and the hollow capsules made by the DNA LbL assembly have been investigated, and it was found that the properties can be controlled by the sequences of the DNA building blocks. Because the additional sequences not for forming the layered structure can be inserted in the building blocks, the functions such as the programmed degradation through competitive hybridization [14], the postcrosslinkable regions to increase the film stability [11], and the sequence to detect specific materials [15-17] can be easily introduced within the film.

The basic building blocks are the homopolymeric diblock nucleotides $\left(\mathrm{A}_{15} \mathrm{G}_{15}\right.$ and $\mathrm{T}_{15} \mathrm{C}_{15}$, Figures $1(\mathrm{a}, \mathrm{c})$ ), and it had been pointed out that the slippage, where each DNA within the double helix can move along the homopolymeric region, assists the regular layer growth in the LbL assembly [7, 8]. This dynamic nature of the DNA stands might not only serve for the functionality such as the programed degradation [14] but also cause instability of the film structure [12].

(a) Type

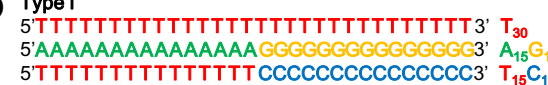

(b) Type II

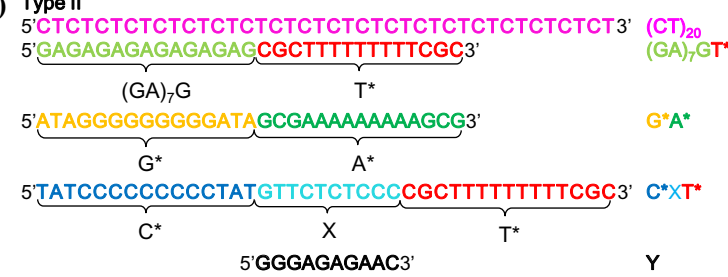

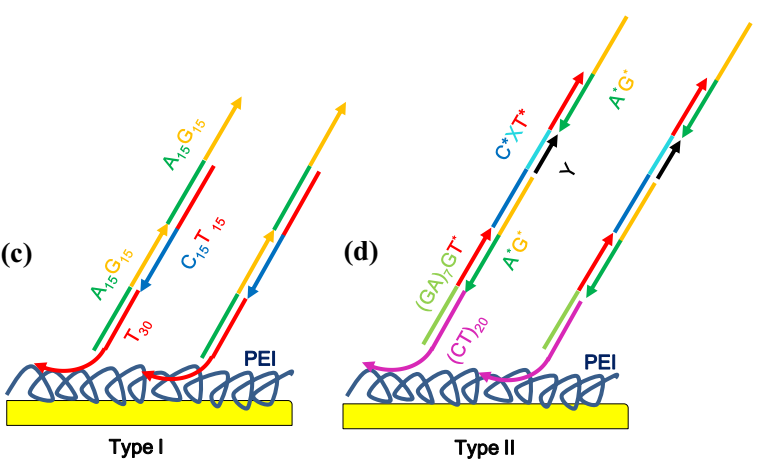

Fig. 1. DNA sequences used to build the films (a) type I and (b) type II. Schematic illustrations of idealized film structures in (c) type I and (d) type II. Polyethylenimine (PEI) is polycation that adsorbs $\mathrm{T}_{30}$ or $(\mathrm{CT})_{20}$ via electrostatic interaction.

Here, we report the DNA LbL film, whose structure was expected to be more stable than that built by the homopolymeric diblocks (Figures 1(a, c), type I). To supress the dynamic nature of the DNA strands, the homogeneity in the sequence was reduced, and the

\footnotetext{
*Corresponding author: nkato@meiji.ac.jp
} 
proposed building blocks (type II) are shown in Figures 1 (b, d). Furthermore, a thermal responsive feature was introduced, i.e., the specific oligomer (oligo Y, Figures 1 (b)) can be released at an elevated temperature. The structural stability against temperatures and ionic strength was compared between the films built using the type I or the type II strands, and the loading and release of the releasable oligo $\mathrm{Y}$ were examined by means of quartz crystal microbalance (QCM). Gel electrophoresis was also performed to investigate whether the DNA building blocks form higher-order complexes in their solution.

\section{Materials and methods}

\subsection{LbL assembly of DNA films}

Pure water $(>18 \mathrm{M} \Omega \mathrm{cm})$ used in the present works was prepared in a Milli-Q system. The buffer solution (SSC buffer) for the DNA consisted of $50 \mathrm{mM}$ sodium citrate with $500 \mathrm{mM} \mathrm{NaCl}$ and its $\mathrm{pH}$ was adjusted by $\mathrm{NaOH}$ to 6.5. The DNA strands were purchased from Hokkaido System Science Co., Ltd. and their purities were greater than $90 \%$. Each DNA was dissolved in SSC buffer at a concentration of $4 \mu \mathrm{M}$ and used for the assembly. The film growth and degradation were monitored using QCM. A quartz crystal oscillator with gold electrodes $(9 \mathrm{MHz}$ AT-cut) was used and its third overtone was monitored by a resonant frequency recorder (QCM934-000, Seiko EG\&G Co., Ltd.). The solutions were injected in the recorder equipped with the oscillator at a flow rate of $1.26 \mu \mathrm{L} / \mathrm{min}$ and the temperature was kept at $25^{\circ} \mathrm{C}$ during the assembly. Because the large dissipation changes were observed during the DNA LbL assembly [8, 10], the Sauerbrey equation [18] does not hold. Therefore, the layer growth and degradation are qualitatively shown as a frequency change $(\Delta f)$. To make the surface charge of the electrode positive, the aqueous solution of polyethylenimine (PEI, Mw $25000,1 \mathrm{mg} / \mathrm{mL}$ ) was injected to the electrode for $10 \mathrm{~min}$, followed by a rinse with SSC buffer for $20 \mathrm{~min}$. On the PEI layer, the first DNA layer $\left(\mathrm{T}_{30}\right.$ and $(\mathrm{TC})_{20}$ in type $\mathrm{I}$ and II, respectively) was adsorbed via electrostatic force. The DNA solution was injected for $3 \mathrm{~min}$, allowing an incubation time of $10 \mathrm{~min}$. This was followed by a rinse with SSC buffer for $7 \mathrm{~min}$ to remove any unhybridized strands. To assemble the film (type I), $\mathrm{A}_{15} \mathrm{G}_{15}$ and $\mathrm{T}_{15} \mathrm{C}_{15}$ were alternately deposited onto the $\mathrm{T}_{30}$ layer. In the case of type II, $(\mathrm{GA})_{7} \mathrm{GT}^{*}$ (the second DNA layer) was deposited onto the $(\mathrm{TC})_{20}$ layer, followed by the alternate deposition of $\mathrm{G}^{*} \mathrm{~A}^{*}$ and $\mathrm{C}^{*} \mathrm{XT}$ *. This film is termed "type II without $\mathrm{Y}^{\prime}$. After the formation of type II without Y, the oligo $\mathrm{Y}$ can be loaded, and such film is termed "type II with postloaded Y". When $\mathrm{G}^{*} \mathrm{~A}^{*}$ and $\mathrm{C}^{*} \mathrm{XT} \mathrm{T}^{*}$ hybridized with Y were alternately deposited onto the $(\mathrm{GA})_{7} \mathrm{GT}^{*}$ layer, the resultant film is termed "type II with preloaded $\mathrm{Y}$ ".

Because the oligo $\mathrm{Y}$ was designed to be released at an inflamed site, the films were exposed to an aqueous $\mathrm{NaCl}$ solution at a physiological ionic strength (IS) of $150 \mathrm{mM}$ at $40^{\circ} \mathrm{C}$ that is higher than the normal body temperature. After the film formation in SSC buffer at $25^{\circ} \mathrm{C}$, the 150 $\mathrm{mM} \mathrm{NaCl}$ solution was injected for at least $25 \mathrm{~min}$. The temperature was then increased to $40^{\circ} \mathrm{C}$, allowing an incubation time for at least $15 \mathrm{~min}$. After this incubation, the temperature was decreased to $25^{\circ} \mathrm{C}$ and the $150 \mathrm{mM}$ $\mathrm{NaCl}$ solution was injected for $15 \mathrm{~min}$, followed by an injection of SCC buffer for $15 \mathrm{~min}$. The frequency of the QCM was then checked to compare with that after the film formation. This treatment with $150 \mathrm{mM} \mathrm{NaCl}$ at $40^{\circ} \mathrm{C}$ was performed not only for inducing the release of $\mathrm{Y}$ but also for examining the tolerance of the film during this treatment. To load the oligo $\mathrm{Y}$ in the film, the solution of $\mathrm{Y}$ was injected for $3 \mathrm{~min}$ at $25^{\circ} \mathrm{C}$ to the film, allowing an incubation time of $10 \mathrm{~min}$. This was followed by a rinse with SSC buffer for $7 \mathrm{~min}$ to remove any unhybridized $\mathrm{Y}$.

The temperature of the treatment with $150 \mathrm{mM} \mathrm{NaCl}$ was changed to 25,30 , or $35^{\circ} \mathrm{C}$ from $40^{\circ} \mathrm{C}$ to investigate the temperature dependence of the fraction of released oligo Y.

\subsection{Gel electrophoresis}

To detect the higher-order complexes of the strands, the native polyacrylamide gels $(950 \times 850 \times 1 \mathrm{~mm})$ were prepared using $40 \% \quad(\mathrm{w} / \mathrm{w})$ aqueous solution of acrylamide/N, N'-methylenebisacrylamide (19:1, BioRad Laboratories Inc.). Ammonium persulfate and N, N, N', N'-tetramethylethylendiamine were used as a polymerization initiator and accelerator, respectively. Tris-borate buffer $(78 \mathrm{mM}, \mathrm{pH} 8.3)$ with $877 \mu \mathrm{M}$ EDTA disodium salt (TBE buffer) was used as an electrophoresis buffer. The DNA ladder (10 bp step, 1 $\mu \mathrm{g} / \mu \mathrm{L}$, Invitrogen ${ }^{\mathrm{TM}}$, Thermo Fisher Scientific Inc.) was denatured by heating at $70^{\circ} \mathrm{C}$ with formamide to create a single-stranded DNA ladder, and the final concentration of the ladder was $0.5 \mu \mathrm{g} / \mu \mathrm{L}$. The sample DNA solutions were prepared using TBE buffer and the concentrations were from 0.2 to $2.0 \mu \mathrm{M}$. $10 \%(\mathrm{v} / \mathrm{v})$ of glycerol was added to the ladder and the sample solutions before being applied to the gel. The pre-electrophoresis was made for $60 \mathrm{~min}$ at constant current of $20 \mathrm{~mA}$. After applying the ladder and the sample solutions to the gel, the electrophoresis was made for $50 \mathrm{~min}$ at constant current of $80 \mathrm{~mA}$. After the electrophoretic separation, the gel was stained by silver to visualize the separated bands using the staining kit (2D-silver stain-II, Cosmo Bio Co., Ltd.).

\section{Results and discussion}

\subsection{Film assembly and stability}

The changes in the frequency of the QCM during the film depositions using the type I strands or the type II stands without $Y$ were observed. After the deposition of the first DNA layer, the frequency was set to 0 , and the frequency changes $(\Delta f)$ from the first DNA layer up to the ninth DNA layer are indicated in Figure 2. Type I showed a greater decrease in $\Delta f$ after the film formation $\left(\Delta f_{\text {build }}\right)$, indicating that the amount of the adsorbed DNA in type I is greater than type II. As pointed out in Ref. [12], in the case of type I, the multiple hybridization might occur due 
to their homopolymeric nature, e.g., two $\mathrm{T}_{15} \mathrm{C}_{15}$ stands can hybridize to one $\mathrm{A}_{15} \mathrm{G}_{15}$ stand. However, such multiple hybridization was suppressed in type II due to the reduction in homogeneity in the sequences of the stands, resulting in the smaller decrease in $\Delta f$ in type II.

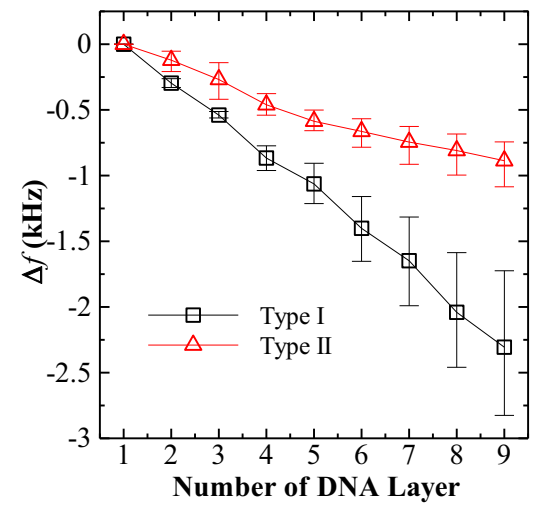

Fig. 2. Frequency changes during the film deposition using the type I strands (open square) and type II strands without Y (open triangle).

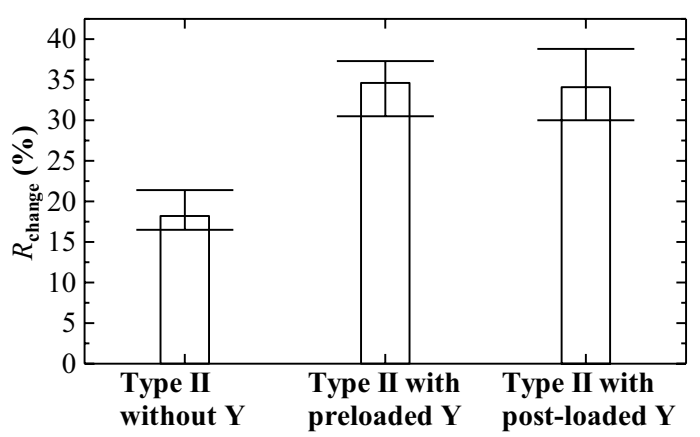

Fig. 3. Values of $R_{\text {change }}$ observed in type II without Y, with preloaded Y, and with post-loaded Y. The films were composed up to the ninth DNA layer.

When the $\Delta f$ after the treatment with $150 \mathrm{mM} \mathrm{NaCl}$ at $40^{\circ} \mathrm{C}\left(\Delta f_{\text {treat }}\right)$ was observed, a desorption of the DNA strands $\left(\Delta f_{\text {build }}<\Delta f_{\text {treat }}\right)$ was observed in both types of films. The rate of change in the frequency after the treatment $\left(R_{\text {change }}\right)$ was calculated as follows; $R_{\text {change }}=$ $\left(\Delta f_{\text {build }}-\Delta f_{\text {treat }}\right) / \Delta f_{\text {build. }}$. The average values of $R_{\text {change }}$ were 65.7 and $18.2 \%$ in type I and type II without $\mathrm{Y}$, respectively. The lower $R_{\text {change }}$ in type II indicates that the film stability was significantly improved by reducing the homogeneity in the sequences of the stands.

Although the stability was improved in type II, still the degradation in type II without Y $\left(R_{\text {change }}=18.2 \%\right)$ was significant enough to disturb the selective release of $Y$ strands. In the idealized structure of type II built up to the ninth DNA layer with the oligo $\mathrm{Y}$, the number ratio of the DNA strands in the film is $(\mathrm{GA})_{7} \mathrm{GT}^{*}: \mathrm{A}^{*} \mathrm{G}^{*}: \mathrm{C}^{*} \mathrm{XT} \mathrm{T}^{*}: \mathrm{Y}=$ $1: 4: 3: 3$. From this ratio, the rate of mass decrease upon release of $\mathrm{Y}$ is calculated to be $14.2 \%$. If the $\Delta f$ is assumed to be proportional to the mass difference, the value of $14.2 \%$ corresponds to $R_{\text {change }}$ upon release of Y. As shown in Figure 3, the values of $R_{\text {change after the }}$ treatment with $150 \mathrm{mM} \mathrm{NaCl}$ at $40^{\circ} \mathrm{C}$ were around $34 \%$ in type II with post-loaded $\mathrm{Y}$ and type II with preloaded $Y$. These values were comparable to the sum of the value of $R_{\text {change }}$ in type II without Y $(18.2 \%)$ and the rate of mass decrease upon release of $\mathrm{Y}$ in the idealized film
$(14.2 \%)$. Thus, the film prepared using the type II strands was not stable enough to realize the selective release of $\mathrm{Y}$ triggered by the treatment with $150 \mathrm{mM} \mathrm{NaCl}$ at $40^{\circ} \mathrm{C}$.

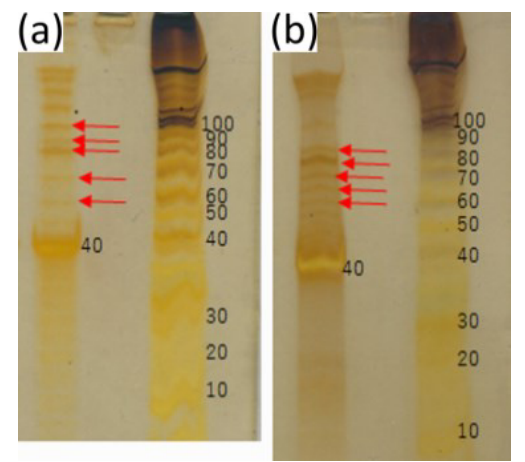

Fig. 4. (a) $(\mathrm{CT})_{20}$ at $0.2 \mu \mathrm{M}$ in left lane and single stranded DNA ladder in right lane. (b) $\mathrm{C}^{*} \mathrm{XT}^{*}$ at $2.0 \mu \mathrm{M}$ in left lane and single stranded DNA ladder in right lane. To guide the eye, the arrows and the numbers of bases are indicated at the bands.

\subsection{Higher-order complexes of the DNA strands}

The DNA strands are able to form higher-order complexes, even if their sequences are not complementary each other [19]. We suspected that the higher-order complexes of the strands in the DNA solutions for the LbL assemble result in the lack of the structural stability of the film. To examine whether the strands shown in Figure 1(b) form the complexes, the electrophoresis using the native acrylamide gel was carried out. Together with the band at 40-mer, $(\mathrm{CT})_{20}$ and $\mathrm{C}^{*} \mathrm{XT}^{*}$ exhibited the bands at larger values than 40 -mer, as shown in Figure 4. In the case of $(\mathrm{GA})_{7} \mathrm{GT}^{*}$ and $\mathrm{G}^{*} \mathrm{~A}^{*}$, the evidence of the complexation was not observed. Because the DNA concentration and the IS of the DNA solution used in the electrophoresis $(0.2$ to $2 \mu \mathrm{M}$ in 78 $\mathrm{mM}$ TBE buffer) were lower than those used in the film deposition $(4 \mu \mathrm{M}$ in $50 \mathrm{mM}$ SSC buffer with $500 \mathrm{mM}$ $\mathrm{NaCl}$ ), the fraction of the complexes of $(\mathrm{CT})_{20}$ and $\mathrm{C}^{*} \mathrm{XT}^{*}$ should be more significant during the film deposition. Therefore, the complexes of the strands should be embedded in the film. Such strands in the embedded complexes were dissociated from the film upon the treatment with $150 \mathrm{mM}$ at $40^{\circ} \mathrm{C}$. This is one of the reasons for the instability of the film made of the type II strands.

\subsection{Loading and release of oligo $Y$}

To realize the film with the function that the oligo $\mathrm{Y}$ was selectively released upon the treatment with $150 \mathrm{mM}$ $\mathrm{NaCl}$ at $40^{\circ} \mathrm{C}$, the film composed up to the ninth DNA layer with preloaded $\mathrm{Y}$ was exposed to the $150 \mathrm{mM} \mathrm{NaCl}$ solution at $40^{\circ} \mathrm{C}$ to destroy the complexes and remove not only the oligo $\mathrm{Y}$ but also the weakly hybridized stands. Into this "pre-treated" film, the oligo Y was reloaded, and the response to the treatment was investigated. Because the mass fraction of $\mathrm{Y}$ in the idealized film is $14.2 \%$ as mentioned above, the mass fraction of the film without $Y$ must be $85.8 \%$. If the mass change is assumed to be proportional to the $\Delta f$ and the rate of the $\Delta f$ after loading 
$\mathrm{Y}$ is normalized to $100 \%$, the rates of $\Delta f$ after releasing $\mathrm{Y}$ and reloading $\mathrm{Y}$ are calculated to be 85.8 and $100 \%$, respectively. When the cycle of reloading and release of $\mathrm{Y}$ is repeated, the rate of $\Delta f$ should change as shown in Figure 5 (open triangle). The rate of $\Delta f$ of the film after the pre-treatment was scaled to be $85.8 \%$, and the change in the rate of $\Delta f$ during two cycles of the reloading and release of $\mathrm{Y}$ was observed and the result is shown in Figure 5 (open square). The good agreement between the calculated and observed data during the two cycles indicates that the "pre-treated" film exhibited a good reproducibility in the reloading of $\mathrm{Y}$ and the selective release of $\mathrm{Y}$ upon the treatment with $150 \mathrm{mM} \mathrm{NaCl}$ at $40^{\circ} \mathrm{C}$.

After reloading Y into the "pre-treated" film, the film was exposed to the $150 \mathrm{mM} \mathrm{NaCl}$ solution at different temperatures and the fractions of released $\mathrm{Y}$ were compared (Figure 6). As we designed, $100 \%$ of the loaded $\mathrm{Y}$ was released at $40^{\circ} \mathrm{C}$. However, $80 \%$ was released at $35^{\circ} \mathrm{C}$ and $20 \%$ was released even at $25^{\circ} \mathrm{C}$, indicated that the oligo $\mathrm{Y}$ is easily released under the normal body temperature. Thus, the current releasable oligo is not suitable enough for the selective release in the inflamed site and has to be improved its thermal stability by adjusting its sequence and the number of bases to increase the hybridization force.

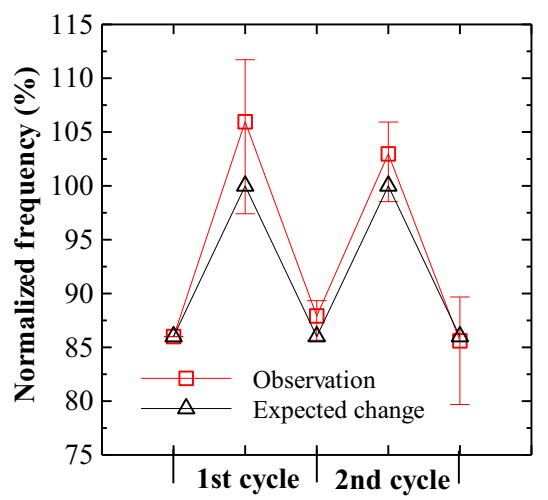

Fig. 5. Repetition of loading and release of $Y$ after the pretreatment. Open squares indicate the obverse data and open triangles indicate the calculated values.

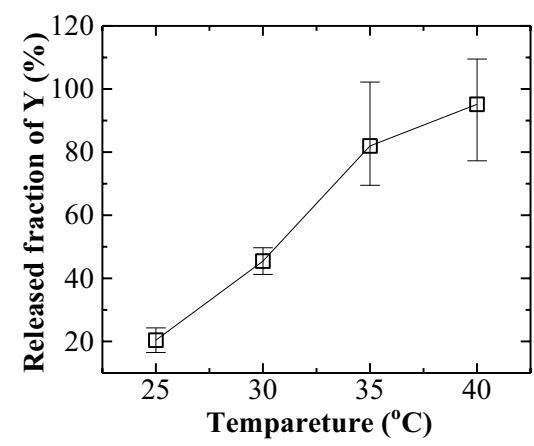

Fig. 6. Temperature dependence of the fraction of released $\mathrm{Y}$. The film after reloading $\mathrm{Y}$ was exposed to $150 \mathrm{mM} \mathrm{NaCl}$ at different temperatures.

\section{Conclusions}

The film assembled by the proposed strands (type II, Figure 1(b)) exhibited a better structural stability toward the treatment with $150 \mathrm{mM} \mathrm{NaCl}$ at $40^{\circ} \mathrm{C}$ than the film assembled by the conventional homopolymeric dilbolck strands (type I, Figure 1(a)). However, the improvement in the stability was not enough for the selective release of the oligo Y. The lack of the film stability was ascribed to the higher-order complexes of the type II strands. After the elimination of these complexes from the film by the pre-treatment with $150 \mathrm{mM} \mathrm{NaCl}$ at $40^{\circ} \mathrm{C}$, the loading and release of $\mathrm{Y}$ can be repeated as we expected. Although the oligo $\mathrm{Y}$ strands were partially released below the desired temperature, the basic concept of the thermal responsive DNA LbL film for the controlled release has been verified.

\section{Acknowledgements}

The authors acknowledge the financial supports from The Institute of Science and Technology, Meiji University and partially from JSPS KAKENHI Grant Number 16K01399. The authors also acknowledge significant experimental support from K. Hattori, N. Ueda, N. Kishi, Y. Inutsuka, and H. Shibuya.

\section{References}

1. G. Decher, Science 277, 1232 (1997)

2. F. Caruso, R.A. Caruso, H. Mohwald, Science 282, 1111 (1998)

3. S. De Koker, R. Hoogenboom, B.G. De Geest, Chem. Soc. Rev. 41, 2867 (2012)

4. W. Tong, X. Song, C. Gao, Chem. Soc. Rev. 41, 6103 (2012)

5. C. Picart, F. Caruso, J.-C. Voegel, Layer-by-Layer Films for Biomedical Applications (Wiley-VCH, Weihheim, Germany, 2015)

6. J.J. Richardson, M. Björnmalm, F. Caruso, Science 348, 411 (2015)

7. A.P.R. Johnston, E.S. Read, F. Caruso, Nano Lett. 5, 953 (2005)

8. A.P.R. Johnston, H. Mitomo, E.S. Read, F. Caruso, Langmuir 22, 3251 (2006).

9. A.P.R. Johnston, F. Caruso, Angew. Chem. Int. Ed. 46, 2677 (2007)

10. L. Lee, A.P.R. Johnston, F. Caruso, Biomacromol. 9, 3070 (2008)

11. A.P.R. Johnston, F. Caruso, Small 4, 612 (2008)

12. N. Kato, L. Lee, R. Chandrawati, A.P.R. Johnston, F. Caruso, J. Phys. Chem. C 113, 21185 (2009)

13. L. Lee, A.P.R. Johnston, F. Caruso, Langmuir 28, 12527 (2012)

14. L. Lee, A.P.R. Johnston, F. Caruso, Small 10, 2902 (2014)

15. Y. Zheng, C. Yang, F. Yang, X. Yang, Anal. Chem. 86, 3849 (2014)

16. H. Xing, N.Y. Wong, Y. Xiang, Y. Lu, Curr. Opin. Chem. Biol. 16, 429 (2012)

17. M. Citartan, S.C.B. Gopinath, J. Tominaga, S.-C. Tan, T.-H. Tang, Biosens. Bioelectron. 34, 1 (2012)

18. G. Sauerbrey, Z. Phys. 155, 206 (1959)

19. E. Protozanova, R.B. Macgregor Jr., Biochem. 35, 16638 (1996) 